DOI: 10.17707/AgricultForest.61.2.14

\author{
Sohrab MORADI, Soleiman MOHAMMADI LIMAEI, \\ Mehrdad KHANMOHAMMADI ${ }^{1}$
}

\title{
CALCULATION OF SEDIMENT YIELD IN THE ZEMKAN RIVER BASIN OF IRAN USING ANALYTICAL METHODS AND GIS CONCEPT
}

\begin{abstract}
SUMMARY
Soil is a living, dynamic and non-renewable source in lifetime which is vital for food production and the global balance of ecosystems. Every year more than 75 billion tons of soil erodes from the surface of earth. Taking care for this, appropriate methods needed to prevent erosion and sediment movement, which in its turn requires the presence of information about erosion intensity in the basin. Lack of statistical data and information on soil erosion and sediment production in Zemkan basin located in the West of Kermanshah Province, is an issue that paved the way to carry out this study with the aim of identification of erosion rate and sedimentation production and exploring sensitive areas of erosion. To achieve the above-mentioned aim, there was used the erosion potential method (EPM) using of geographical information system (GIS) to reduce errors and increase the relative accuracy in the analysis of the model. Required data in this study were prepared through field observations, existing maps, statistics of meteorological and hydrometric stations and library resources. After inputting maps into the ArcGIS software environment and geo-referencing them, required layer was digitized and there created database for them. Finally, using standard tables provided in the EPM model, accordant values for the basin extracted and incorporated into the layers according to the relations given in EPM model, map of erosion intensity zoning, erosion and sediment ratio calculated for the basin. Results showed that the rates of especial erosion (WSP) and especial sediment are (GSP), 2742.02 and $1005.55 \mathrm{~m} 3 / \mathrm{Km} 2 / \mathrm{y}$ respectively. Class and intensity of erodibility of basin were also identified as very intensive (V). Therefore, different policies of erosion control in the basin are necessary.
\end{abstract}

Keywords: EPM Model, Erosion, GIS, Sediment, Zemkan basin

\section{INTRODUCTION}

One of the most important natural resources of any country is soil (Maghsoudi et al., 2009). Soil is a living, dynamic and non-renewable resource in

1 Sohrab MORADI, (corresponding author: Moradi_4@pnu.ac.ir), PhD student in Guilan University \& Instructor, Department of Natural resources, Payame Noor University, Tehran, Iran, Soleiman Mohammadi LIMAEI, Mehrdad KHANMOHAMMADI, Assistant Professor, Faculty of Natural Resources, Guilan University, Someh Sara, Rasht (Iran),

Notes: The authors declare that they have no conflicts of interest. Authorship Form signed online. 
lifetime of human that is vital for food production, and global balance of ecosystems (Bracken and Kirkby, 2005). Soil and water resources, economically and ecologically, are known as key components of natural resources and development of agricultural activities and in fact, they are the origin of producing human's basic needs and provider of natural needs of plants and organisms in ecosystem (Ghanbarzadeh and Gholamrezaee, 2007). Today, accelerated soil erosion is considered as a global problem because of its impact on economy and environment (Kyoung et al, 2005). According to estimation of Food and Agriculture Organization, every year more than 75 billion tons of soil is eroded from the Earth's surface that is equal to $134 \mathrm{ton} / \mathrm{Km}^{2}$ (Sobhani, 2002). Also almost two billion tons of valuable soils is lost annually in Iran (Gholami, 2003), as during the years 1951 to 1999 the rate of soil erosion in Iran has increased $450 \%$ (Ahmadi, 1999). This indicates the criticality of the status of erosion and the need for its control in Iran.

Shortage of hydrometric stations in most mountainous areas of the West country, has been the cause for lack of correct identification of areas susceptible to erosion in surface of basins, so that through taking measure appropriate with the circumstances prevent removal of this national capital. Lack or extreme scarcity of data and statistics in the field of soil erosion and sediment production in the study area (Zemkan basin) has brought problems for residents, including decrease of productive potential of land, damage to roads, obstruction of bridges and irrigation channels and destruction of gardens and lands along river of the basin. Thus, currently the problem of soil erosion and its impacts in the study area is considered as a serious problem; that through a true understanding of the processes governing the erosion and obtaining relatively accurate estimation of sediment rates and waste of soil based on appropriate empirical methods, the most suitable way to control and inhibit the erosion can be provided. Among the provided experimental methods and models (FAO, BLM, EPM and PSIAC), application of experimental models PSIAC and EPM has attracted more attention of domestic experts and scholars (Rastgou, et al, 2006). Therefore, efficiency of using EPM model in basins of Iran has been proven (Sokouti et al, 2001). EPM model includes determining intensity of erosion in a basin, measuring rate of sediment transport and calculating sedimentation rate in different parts of a basin (Ghazavi et al, 2012) which was obtained using data from pieces of erosion lands and measuring sediment after 40 years of research in the former Yugoslav presented for the first time in 1988 by Gavrilovic at the International Conference on River Regime (Refahi, 2003); and also has been applied in various fields in Iran (Refahi \& Nematti, 1995- Sadeghi, 1993- Tangestani 2001 and 2006); their studies indicate acceptability of the results of EPM model. Devente et al. (2005), by doing a study for prediction of sediment production at basin scale concluded that in order to get closer to the reality of sediment production in each basin, in use of these models, topographic data and satellite images should be used in addition to using semi-quantitative models, for the better implementation of the results. 
Recently, precise system of GIS with great functions has enabled us to store, retrieve, and update basic information in form of layers or information tables. Using this system, human error factors can be minimized (Shirzadi, 2009). There is some researches in the field of using GIS and remote sensing for estimating erosion and sediment, including the works by Hill (1993), Ziaee Esfandrany (2004), Gobin et al (2003), Jalili et al (2005), Amini et al (2010), Borzoo et al (2008), Amiri (2010) and Rangzan and Moradzadeh (2005). Bagherzadeh (1993) investigated the efficiency of several models such as EPM model in Ozon Darreh basin for determining the efficiency of erosion and sediment. Bayat (2001) also in a study to evaluate efficiency of MPSIAC and EPM models in estimation of erosion and sediment of Taleghan basin using GIS investigated these two models. Rangzan et al (2007) in a study in a basin of Khuzestan in Iran, after comparing the two methods of MPSIAC and EPM, concluded that the results obtained by both methods are consistent in most regions. This study examines the process of erosion and sedimentation using modern techniques in the study area.

\section{MATERIAL AND METHODS}

\section{Study area}

Zemkan basin is one of the largest basins of Kermanshah Province that is located between longitudes $45^{\circ} 52$ ' $10^{\prime \prime}$ and $46^{\circ} 35^{\prime} 05^{\prime \prime}$ East and latitudes $34^{\circ} 13^{\prime}$ $45^{\prime \prime}$ and $35^{\circ} 02^{\prime} 45^{\prime \prime}$ North. Its area is $2338 \mathrm{Km} 2$ and its circumference is $314 \mathrm{~km}$ (Figure 1). The average altitude of this basin is $1502 \mathrm{~m}$ (maximum $2547 \mathrm{~m}$ and minimum $514 \mathrm{~m}$ ). Zemkan basin consists of three sub basins of Zemkan, Gerdi Ghaseman and Dallahoo, with areas of 1414, 503 and $421 \mathrm{Km} 2$, respectively .Its main river called Zemkan with length of $125 \mathrm{Km} 2$ drainages all area of the basin and enters Sirwan river in Iraq country.

Regarding climate Zemkan basin is located in semi-humid moderate zone and its major source of rainfall is mountains. The average annual rainfall in basin of Zemkan has been recorded as $450 \mathrm{~mm}$ and average of annual temperature as $15.8^{\circ} \mathrm{C}$.

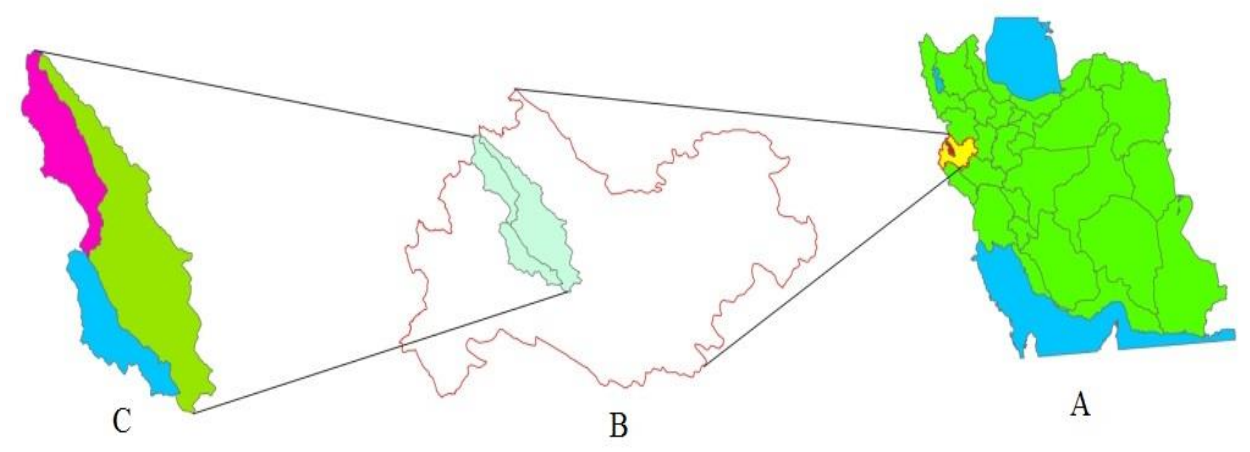

Figure 1. The position of study area A. Iran B. Kermanshah Province C. Zemkan basin 


\section{Required maps and data}

In this study, the following maps and data, according to the nature of research and the methods have been used:

A.Statistics and information including meteorological data, information and maps of the study area in relation to the subject, including data and information relating to the Iranian Meteorological Agency and Forests, Rangelands and Watershed Management Organization were collected.

B.Topographic maps with a scale of 1: 50000 from National Geography Organization of Iran to prepare thematic maps.

C.Regional geological map with a scale of 1: 100,000 for preparing lithology maps and formation of the region.

D.IRS-P6 satellite images of LissIII and LissIV sensors belonging to 2008 from National Geography Organization of Iran to prepare land use maps of the study area.

E.Use of software packages ArcGIS, PCI Geomatica and Excel to analyze and extract basic information and maps needed.

\section{Method}

In this study, for estimating intensity of erosion and sedimentation potential of basin under study, EPM model and RS and GIS techniques have been used. After inputting the maps into ArcGIS software and making them georeferenced, requiring layers were digitized and database for them were created. Using EPM model, affecting factors to the erosion in the basins were assessed and scored. In this method the following Coefficient of erosion intensity were estimate, Basin erosion coefficient $(\Psi)$, land use coefficient $(\mathrm{Xa})$, coefficient of susceptibility of rock and soil to erosion (Y) and average slope of basin (I) in different sub basins and finally the entire basin. In each sub basins based on mentioned before factors, value of $\mathrm{Z}$ or coefficient of erosion intensity, average annual special sediment (Amount of sediment production per unit area) and the amount of sediment produced were calculated during the year in sub basins and finally in total basin..

As mentioned before, for ease and accuracy of work in getting the amount of erosion and sediment production, first the entire basin of Zemkan was divided to three sub basins named Gerdi Ghaseman, Dallahoo and Zemkan. Then affecting factors in production of sediment in each of the sub basins were studied. In the final stage, rate of erosion and sediment production were calculated using related formula and coefficients. Each of the four factors will be examined later.

\section{A- Observational erosion coefficient ( $\Psi$ )}

Observational erosion coefficient indicates the appearance of erosion in the area. This coefficient is determined through field visits conducted in the region and using Table 1. In this study, in addition to Table 1, the map of the geomorphology of the basin has been used for determining erosion coefficient. According to Table 1, erosion coefficient in each sub basins has been calculated and the results are shown in Figure 2. 
Table 1. Values of observational erosion coefficient ( $\Psi$ ) (Ahmadi, 1999)

\begin{tabular}{|l|c|}
\hline \multicolumn{1}{|c|}{ Erosion conditions of the basin } & Mean values \\
\hline The area has many Gullies and severe erosion & 0.9 \\
\hline About 80\% of the area has groove-gully erosion & 0.8 \\
\hline About 50\% of the area has groove-gully erosion & 0.7 \\
\hline $\begin{array}{l}\text { The total area has surface erosion, sediment and debris, and } \\
\text { little groove-gully erosion }\end{array}$ & 0.6 \\
\hline $\begin{array}{l}\text { The total area has surface erosion, but with no traces of deep } \\
\text { erosion (gullies, grooves and debris) }\end{array}$ & 0.5 \\
\hline $\begin{array}{l}\text { 50\% of the area has Surface erosion and the remaining with } \\
\text { no erosion }\end{array}$ & 0.4 \\
\hline $\begin{array}{l}\text { 20\% of the area has Surface erosion and the remaining with } \\
\text { no erosion }\end{array}$ & 0.3 \\
\hline $\begin{array}{l}\text { Ground Surface is without visible erosion, but along the } \\
\text { river, debris and landslides are observed }\end{array}$ & 0.2 \\
\hline $\begin{array}{l}\text { Ground Surface is without visible erosion and usually has } \\
\text { agricultural coverage }\end{array}$ & 0.1 \\
\hline $\begin{array}{l}\text { Ground Surface is without visible erosion and is often } \\
\text { covered by Permanent plants and forest }\end{array}$ & \\
\hline
\end{tabular}

\section{B- Land use coefficient (Xa)}

This coefficient is related to the type of land use and scores related to different uses in sub basins are specified through land use map (Figure 3) and according to Table 2. For preparing land use map, images of IRS-P6 satellite from LissIV and LissIII sensors belonging to 2008 from National Geography Organization of Iran were used. After performing radiometric and geometric corrections by PCI Geomatica software, classification was done using training points. Moreover, visual interpretation was performed and the land use map was prepared. According to Table 2 and land use map (Figure 3), coefficients of using land in each sub basin were calculated (Figure 4).

Table 2. Score of land use coefficient (Xa) (Refahi, 2003)

\begin{tabular}{|l|c|}
\hline \multicolumn{1}{|c|}{ Land use conditions } & Mean values \\
\hline Non-arable lands and Badlands & 1 \\
\hline Tapa Mahoor and plowed lands for agriculture & 0.9 \\
\hline Fruit gardens, vineyards without pastures vegetation & 0.8 \\
\hline Plowed fields on the contour line & 0.7 \\
\hline Ruined and eroded forests and formed Scrubs on worn soils & 0.6 \\
\hline Dry mountainous pastures & 0.5 \\
\hline Permanent farms and hay lands & 0.4 \\
\hline Drained and covered with grass pastures & 0.3 \\
\hline Good forests on steep slopes & 0.2 \\
\hline Good forests on gentle slopes & 0.1 \\
\hline
\end{tabular}




\section{C-Coefficient of susceptibility of rock and soil to erosion (Y)}

Physical properties of rocks against the climate and biological effects have decisive role, (Mahmmudi, 2004). In other words, rocks and non-dense deposits of ground surface are in different classes regarding resistance to erosion. Thus, to estimate the rate of erosion and production of sediment in the EPM method, it is necessary to assess susceptibility of rocks in the study area. In the study after preparing geology and lithology map of the area (Figure 5), through scanning the paper map with scale of 1:100,000 and its digitization in software Arc GIS, according to table of coefficient of susceptibility of rock and soil to erosion (Table 3), the score in different sub basins and finally the whole basin was determined (Figure 6).

Table 3. Values for rock and soil susceptibility to erosion (Y)

\begin{tabular}{|l|c|}
\hline \multicolumn{1}{|c|}{ Conditions of rock and soil } & Mean values \\
\hline Sand, gravel, schist & 2 \\
\hline Loess, tuff, salty soil and steppe soil & 1.6 \\
\hline Weathered rock and marl & 1.2 \\
\hline red sandstone, Serpentine and flysch sediments & 1.1 \\
\hline $\begin{array}{l}\text { Podzol, para podzol , crushed schist, mica schist, gneiss, } \\
\text { argillite schist }\end{array}$ & 1 \\
\hline Hard limestone, litter, humus and silicate-bearing soils & 0.9 \\
\hline Brown forest soils and mountain soils & 0.8 \\
\hline marshy soils and black or dark gray hydro morph & 0.6 \\
\hline Chernozem and fine-textured alluvial sediments & 0.5 \\
\hline Hard Igneous rocks & 0.25 \\
\hline
\end{tabular}

\section{D-The average slope of the basin (I)}

In this study, for extracting the slope parameter, using map of digital elevation model (DEM) and the SLOPE command in the software environment of Arc GIS, the map of average slope has been obtained (Figure 7). With regard to the four factors calculated in the previous step (Observational erosion coefficient, Land use coefficient, susceptibility of rock and soil to erosion and basin's average slope), Z value or coefficient of erosion intensity for each sub basin and finally for total area was calculated using equation 1 (Gavrilovic, 1988).

$$
Z=Y . X a(\Psi+I 0.5)
$$

By calculating the coefficient of erosion intensity and placing that value in standard table (Gavrilovic, 1988), that has been set based on the erosion intensity and coefficient of erosion intensity (z), erosion class of each sub basin is specified and the results are shown in Figure 8. 
Table 4: Classification of erosion intensity

\begin{tabular}{|c|c|c|c|}
\hline $\begin{array}{c}\text { The average value } \\
\text { of } \mathrm{Z}\end{array}$ & $\mathrm{Z}$ range & $\begin{array}{c}\text { Quality } \\
\text { erosion class }\end{array}$ & $\begin{array}{c}\text { Erosion } \\
\text { class }\end{array}$ \\
\hline 1.25 & $>1$ & Very high & V \\
\hline 0.85 & $1>\mathrm{Z}>0.71$ & High & IV \\
\hline 0.55 & $0.7>\mathrm{Z}>0.41$ & medium & III \\
\hline 0.3 & $0.4>\mathrm{Z}>0.2$ & Low & II \\
\hline 0.1 & $\mathrm{Z}<0.19$ & Very low & I \\
\hline
\end{tabular}

In EPM method, to estimate the average annual special erosion rate, that in facts shows rate of erosion in area unit of basin (ha or $\mathrm{Km} 2$ ) equation (2) is used (Refahi, 2003):

$$
\mathrm{Wsp}=\text { Т. Н. Л. } \mathrm{Z}^{1.5}
$$

Where Wsp: average annual special erosion, in $\mathrm{m} 3 / \mathrm{Km} 2 . y r, \mathrm{H}$ : annual average Precipitation $(\mathrm{mm}), \pi: 3.14$, and $\mathrm{T}$ : temperature coefficient that is obtained from equation 3 (Refahi, 2003).

$$
\mathrm{T}=[(\mathrm{t} / 10)+0.1]^{0.5}
$$

Where t: average annual temperature in centigrade degree. After calculating the special erosion, erosion rate at each sub basin and finally the total basin is calculated using equation 4 :

$$
\mathrm{W}_{\mathrm{S}}=\mathrm{W}_{\mathrm{SP}} \times \mathrm{A}
$$

Where $\mathrm{W}_{\mathrm{S}}$ : the total erosion of basin in cubic $\mathrm{m}$ per year, and $\mathrm{A}$ : area in $\mathrm{Km} 2$. The Wsp calculated in the above equation represents the amount of soil that was removed and transferred from his bed, but all the eroded material do not get the outlet of basin and the amount of soil eroded that will turn to output sediment depends on several variables that in fact affect proportion of sedimentation of the basin. In this model, a coefficient is used for the conversion of rate of erosion to sediment that is called sedimentation coefficient of basin. By applying this coefficient it is determined that how much sediment will be removed from the output point of basin. In EPM method, sedimentation coefficient is obtained based on equation 5 (Ghanbarzadeh and Gholamrezayee, 2007), using factors such as the circumference, length, and height difference of the basin.

$$
R u=[4(\mathrm{P} \times \mathrm{D}) 0.5] /[\mathrm{L}+10]
$$

Where $R u$ : coefficient of sedimentation, P: circumference of the basin per $\mathrm{Km}$, L: length of the main channel in $\mathrm{Km}$, D: average of height difference in basin in $\mathrm{Km}$ that is calculated by equation 6 :

$$
\mathrm{D}=\mathrm{D}_{\mathrm{av}}-\mathrm{Do}
$$


Where $\mathrm{D}_{\mathrm{av}}$ : average height of basin in $\mathrm{Km} 2$ and DO: height of outlet point in river in $\mathrm{Km}$. Then, value of $\mathrm{D}$ is calculated and put in equation 4 , and sedimentation coefficient of basin is calculated. The special sediment is calculated from equation 7 :

$$
\mathrm{G}_{\mathrm{SP}}=\mathrm{W}_{\mathrm{SP}} \times R u
$$

Where $\mathrm{G}_{\mathrm{SP}}$ : special sediment $(\mathrm{m} 3 / \mathrm{y} / \mathrm{Km} 2)$. Finally, total sediment of basin is obtained from equation 8 :

$$
\mathrm{G}_{\mathrm{S}}=\mathrm{G}_{\mathrm{SP}} \times \mathrm{A}
$$

Where $\mathrm{G}_{\mathrm{s}}$ : total sediment (m3/y) and A: area of basin in $\mathrm{Km} 2$.

\section{RESULTS AND DISCUSSION}

The results of calculation of the values of erosion intensity coefficient $(\mathrm{Z})$ (Figure 8) based on the values of the coefficients Xa (Figure 2), Y (Figure 4), $\Psi$ (Figure 6) and I (Figure 7), the special erosion (WSP), total erosion (WS), coefficient of sedimentation (Ru), special sedimentation (GSP) and total sediment (GS) have been calculated in sub basins and total basin separately. It should be mentioned that the values of the erosion coefficient, special erosion, and total erosion, coefficient of sedimentation, special sediment and total sediment in each sub basin and total basin are given in Table 5. Based on this, special erosion rate and total erosion in Zemkan basin is 2.74 (ton/Km2.yr) and 6,409 (ton/yr) respectively. In addition, amount of special sediment and total sediment in Zemkan basin is 1.005 (ton/Km2.yr) and 2,350 (ton/yr) respectively.

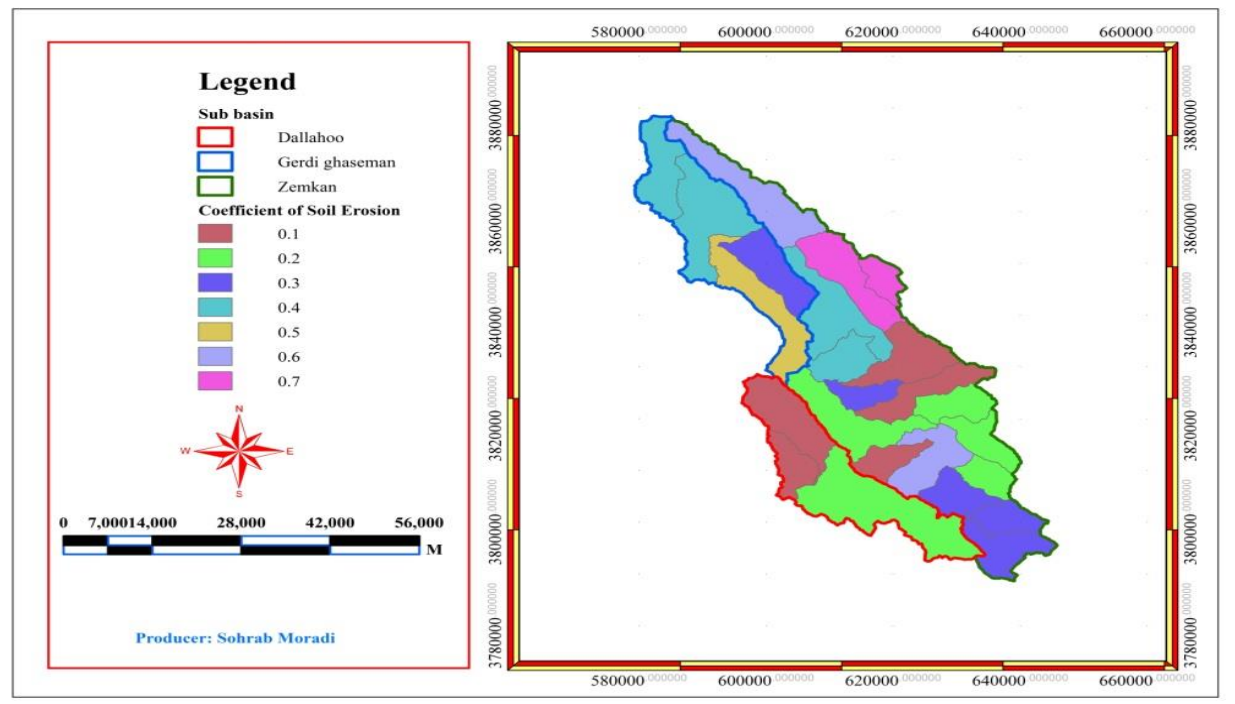

Figure 2. Coefficient of soil erosion map in sub basin of Zemkan using EPM model 


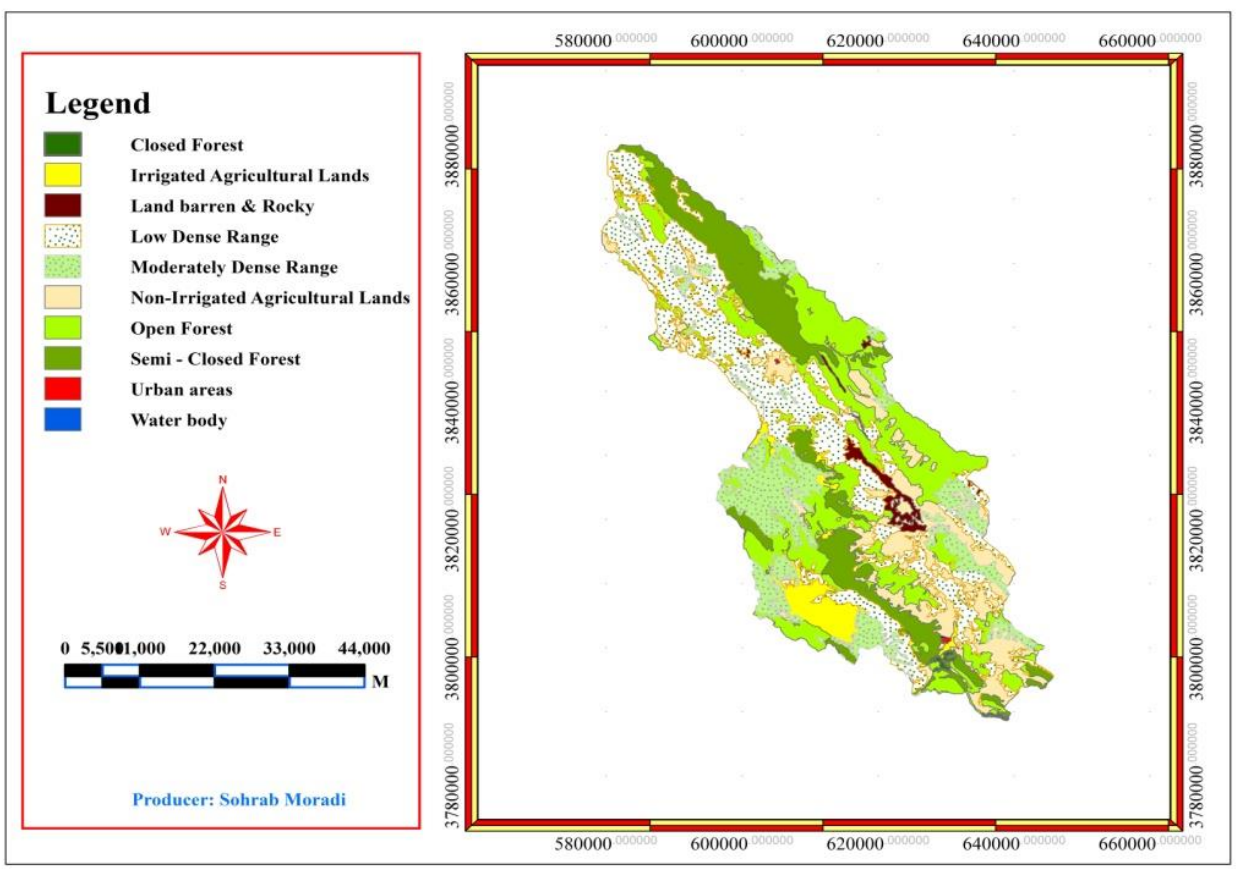

Figure 3. Land use map of Zemkan basin

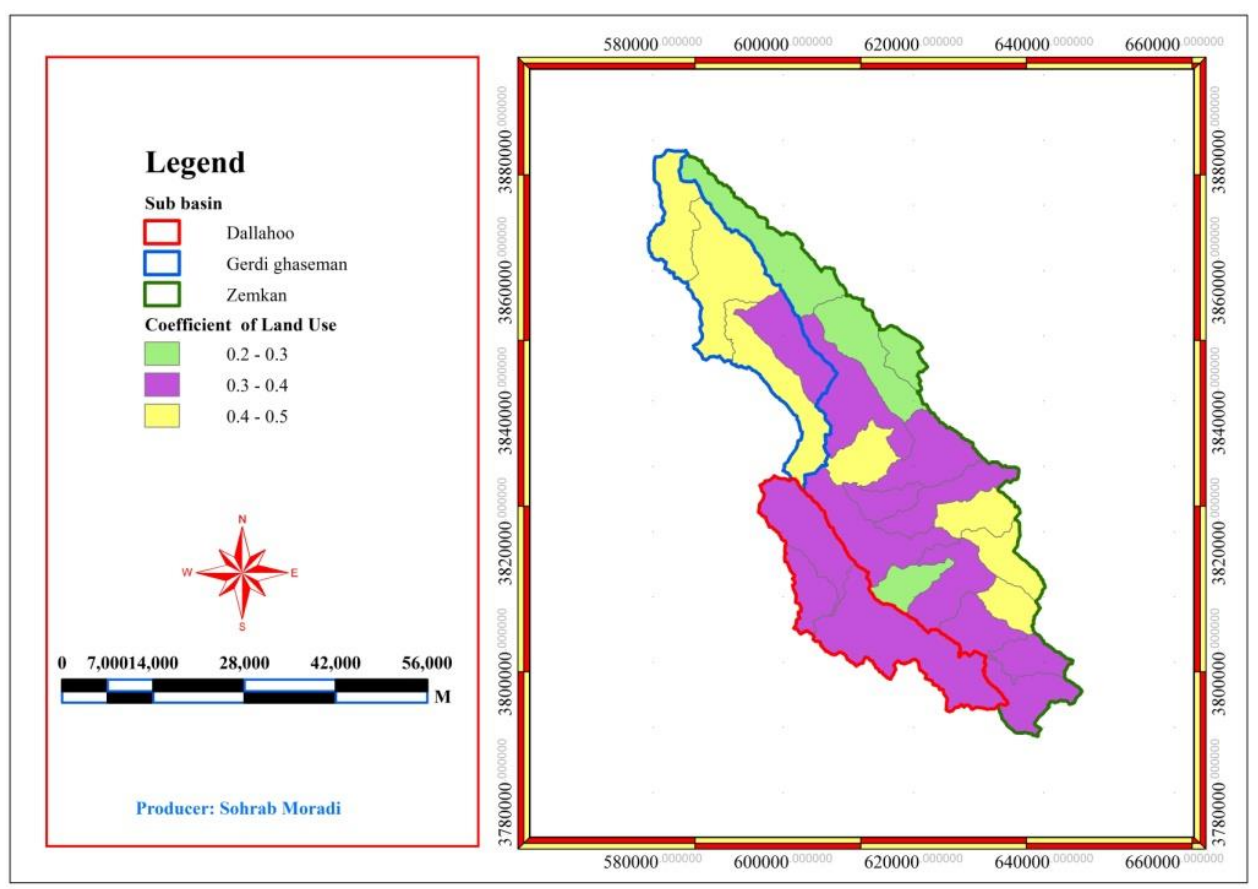

Figure 4. Coefficient of land use map in sub basin of Zemkan using EPM model 


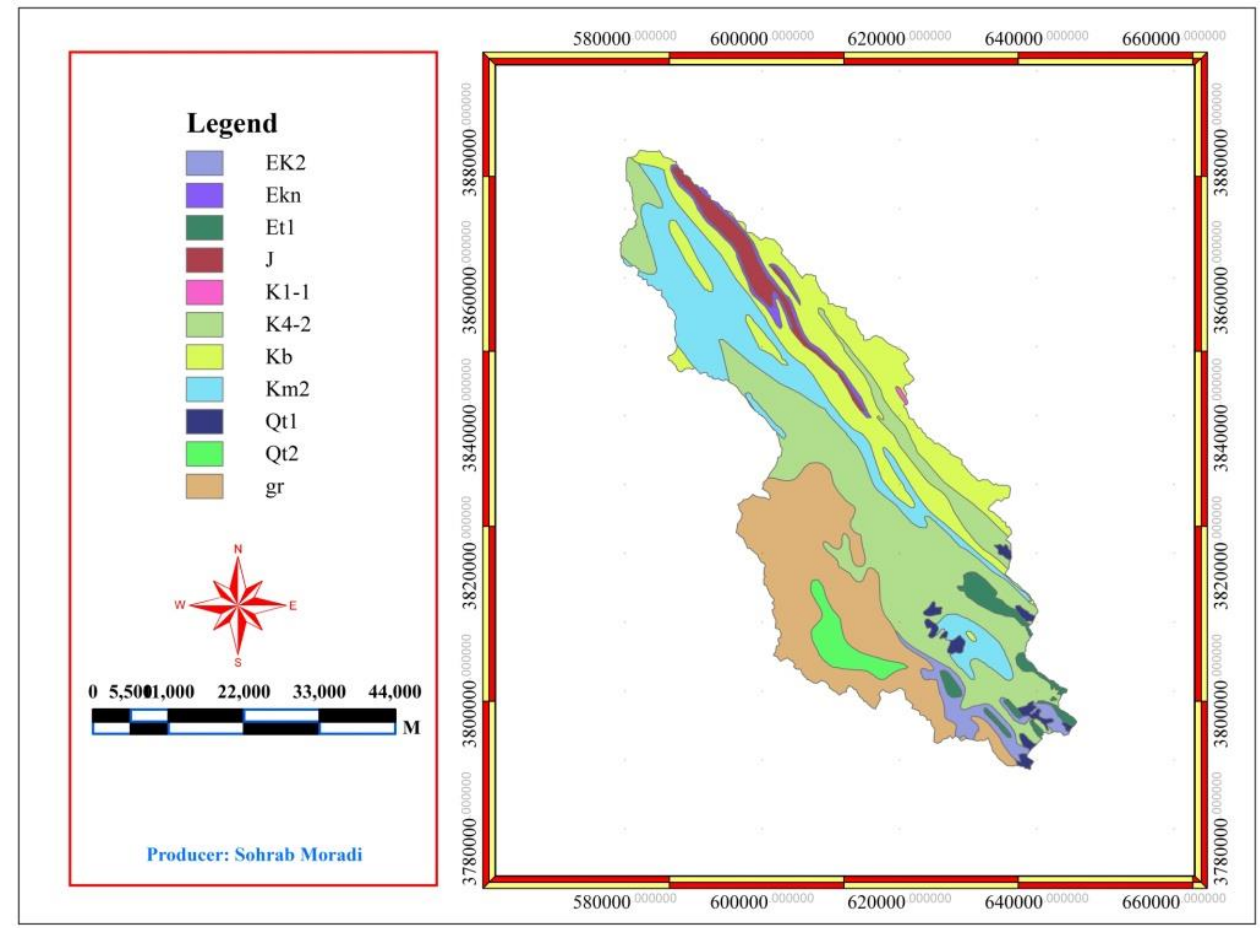

Figure 5. Lithology map of Zemkan basin

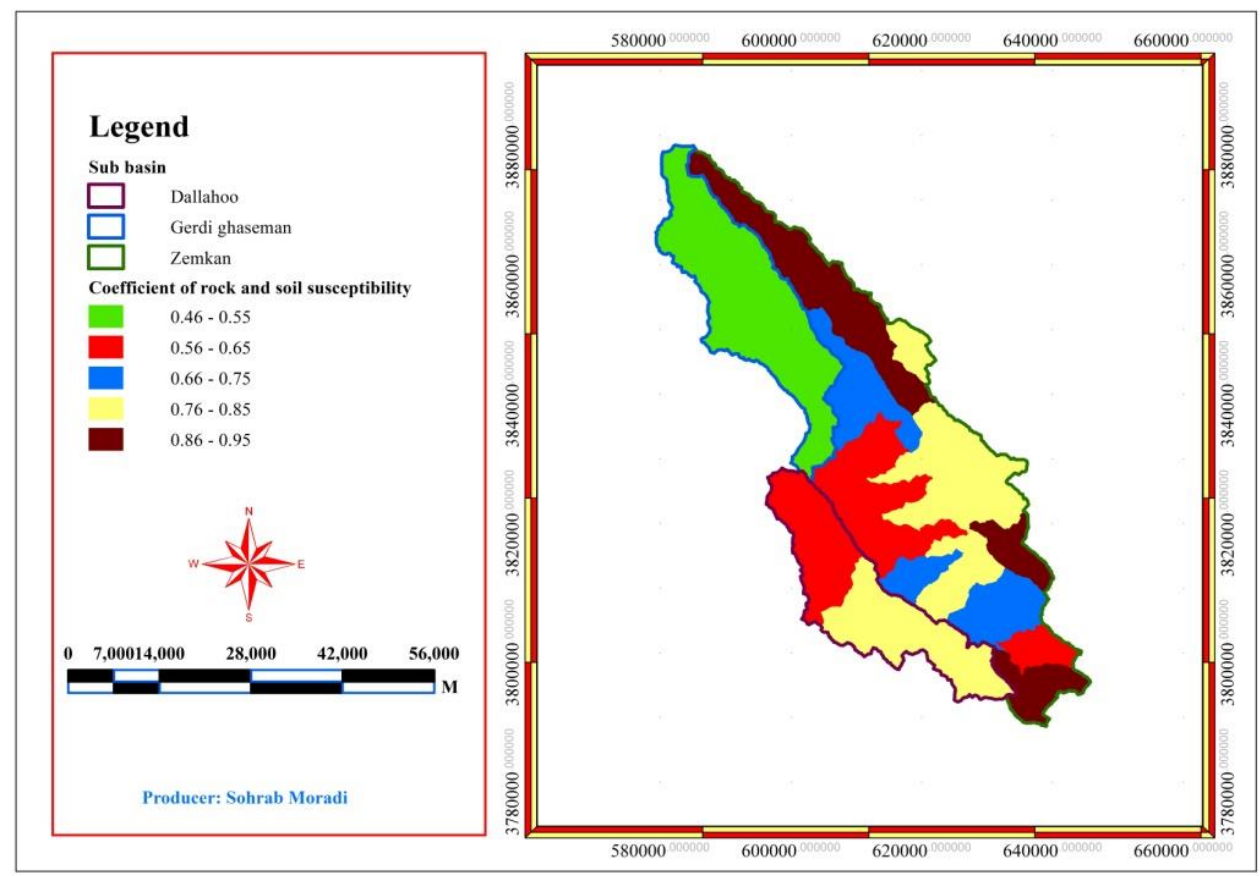

Figure 6. Coefficient of rock and soil susceptibility map in sub basin of Zemkan using EPM model 


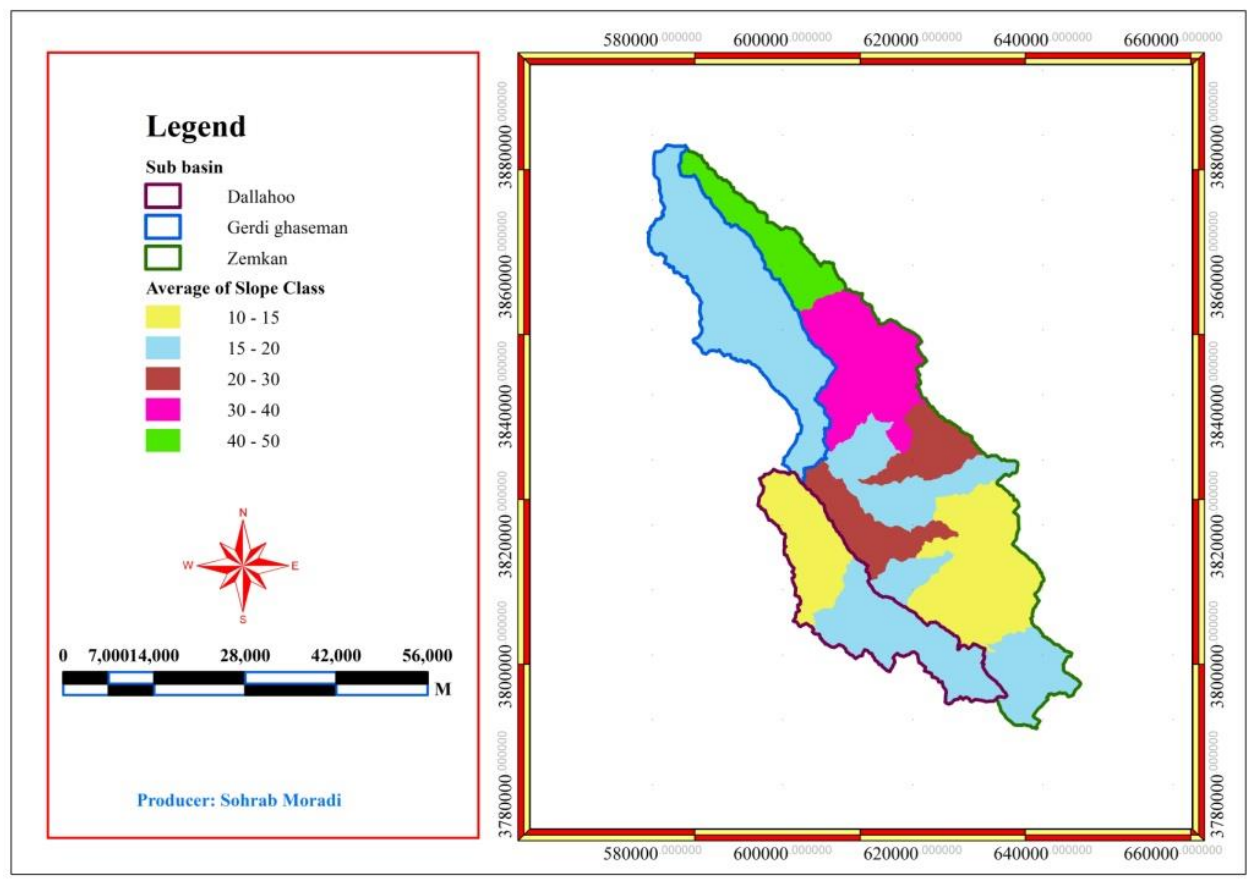

Figure 7. Average of slope map in sub basin of Zemkan

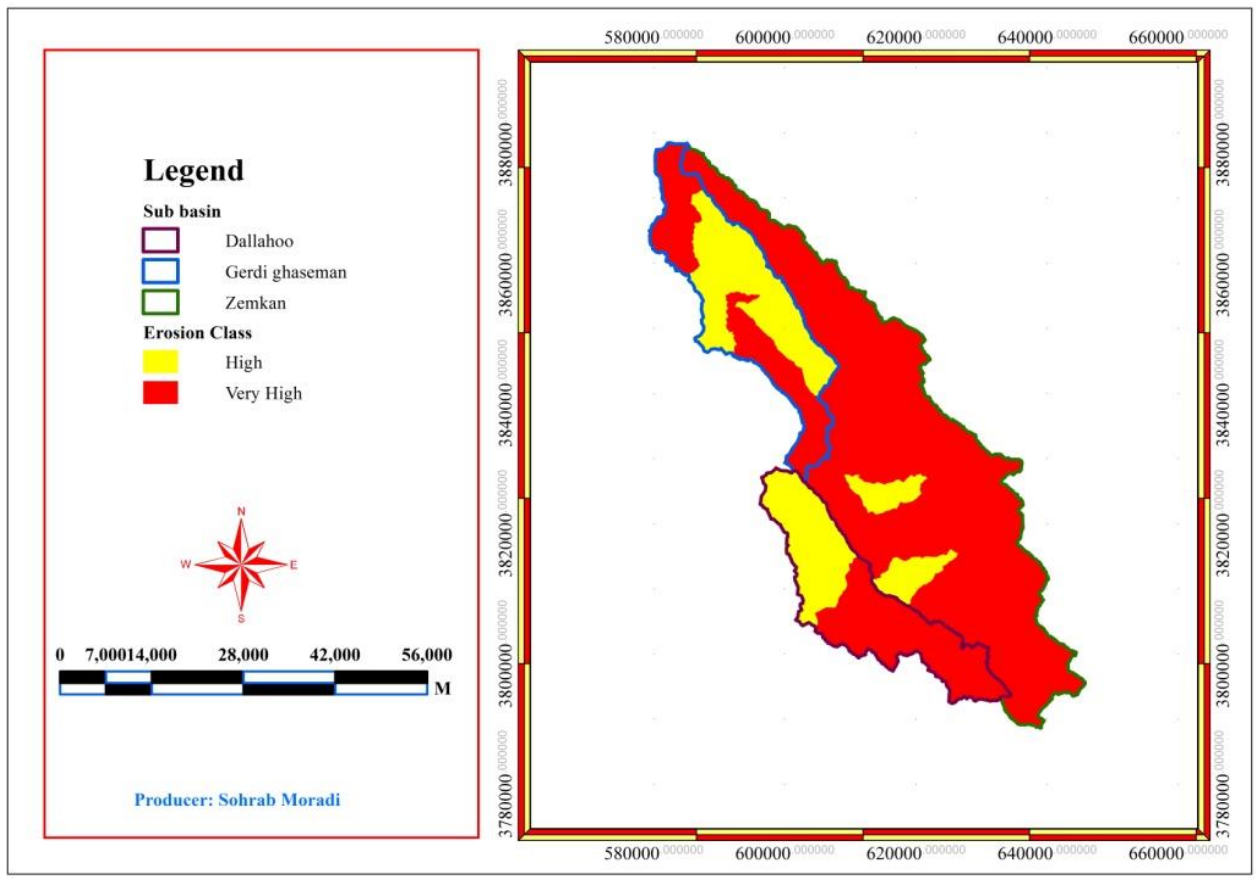

Figure 8. Map of erosion class in sub basin of Zemkan 
Table 5. Result of erosion and Sediment in sub basins of Zemkan using EPM model

\begin{tabular}{|c|c|c|c|c|}
\hline $\begin{array}{ll}\text { Parameter } & \text { Sub basin }\end{array}$ & $\begin{array}{c}\text { Gerdi } \\
\text { Ghaseman }\end{array}$ & Dallahoo & Zemkan & Total \\
\hline Area $(\mathrm{Km} 2)$ & 502.6 & 421.08 & 1413.74 & 2337.42 \\
\hline Average slope of the basin (I) & 20.83 & 23.89 & 14.34 & 17.68 \\
\hline $\begin{array}{l}\text { Coefficient of rock and soil } \\
\text { susceptibility (Y) }\end{array}$ & 0.71 & 0.77 & 0.72 & 0.51 \\
\hline $\begin{array}{l}\text { Observational erosion coefficient } \\
(\Psi)\end{array}$ & 0.32 & 0.34 & 0.13 & 0.4 \\
\hline Land use coefficient $(\mathrm{Xa})$ & 0.37 & 0.34 & 0.38 & 0.43 \\
\hline Erosion intensity coefficient (Z) & 1.26 & 1.37 & 1.06 & 1 \\
\hline Erosion class & $\mathrm{V}$ & $\mathrm{V}$ & $\mathrm{V}$ & IV \\
\hline Quality erosion class & Very high & Very high & Very high & High \\
\hline $\begin{array}{l}\text { Special erosion } \\
(\mathrm{m} 3 / \mathrm{Km} 2 . y \mathrm{r})\end{array}$ & 2742.02 & 3113.94 & 2116.31 & 1934.51 \\
\hline Total erosion (WS) (m3/yr) & 6409261.13 & 4402308.85 & 891137.11 & 972286.35 \\
\hline Sedimentation coefficient $(\mathrm{Ru})$ & 0.367 & 0.494 & 0.036 & 0.551 \\
\hline $\begin{array}{ll}\text { special } & \text { sediment } \\
(\mathrm{m} 3 / \mathrm{Km} 2 . \mathrm{yr})\end{array}$ & 1005.55 & 1539.140 & 76.259 & 1065.283 \\
\hline Total sediment (GS) (m3/yr) & 2350383.59 & 2175943.47 & 32111.05 & 535411.3 \\
\hline
\end{tabular}

\section{CONCLUSIONS}

In performing calculation related to EPM model, the coefficients mean of observational erosion $(\Psi)$, land use $(\mathrm{Xa})$, soil and rock susceptibility to erosion (Y), and average slope of the basin (I) are calculated and through comparison with standard tables, rate and class of erosion for each sub basin and total area were estimated. The erosion intensity coefficient $(Z)$ in sub basins of Gerdi Ghaseman, Dallahoo and Zemkan was calculated respectively as 1, 1.06 and 1.37, and in total area as 1.26 (Table 5); that's according to standard table (Table 4), class and intensity of erosion of sub basin Gerdi Ghaseman is in High group (IV) and other sub basins and total basin is in very High group (V). In addition, rate of special erosion (WSP) and special sediment (GSP) of total basin was estimated respectively as 2742.02 and $1005.55\left(\mathrm{~m}^{3} / \mathrm{Km}^{2}\right.$.yr). Investigation of erosion intensity map (Figure 8) showed that in all hydrological units of sub basins Gerdi Ghaseman, Dallahoo and Zemkan, for each sub basin only two hydrologic unit indicates in High erosion class and in all other hydrological units, in all sub basins, very high erosion rate is dominant; that generally indicates a very high erosion status in total basin of Zemkan but the impact of each of factors on the erodibility rate of the basin is completely different.

One of the factors affecting erosion and sediment yield is rainfall regime and climate of the basin, that by its investigation it was found that much of Precipitation in basin of Zemkan is rain and in winter, it is associated with snow. Although by melting snow, surface runoffs start to flow and intensify soil mass movement; but through field investigations, mass movements of soil were not observed in basin area, but rainfall especially with high intensity and short time 
caused rapid flow and runoff intensity that destroys large amount of surface soil and carries it as sediment and suspended sediment to downstream areas of basin.

Other factors affecting erosion and sediment production and creation of basin flood are physiographic and topographic features such as slope, elevation, and waterways' status (Ghanbarzadeh and Gholamrezayee, 2007). Slope of Zemkan basin in most parts of it is considerable, so that in many parts of the Gerdi Ghaseman sub basin it is more than 30\%. The average slope of total basin is $20.83 \%$, which is effective in accelerating erosion, and the parameter affecting it including runoff. Generally, in areas with gentle slope because the power of flowing waters decrease, so less erosion can be seen in various forms; while in Zemkan basin due to its being mountainous, in most parts of it the opposite situation occurs. Drainage density of basin is about $4 \mathrm{Km}$ in $\mathrm{Km}^{2}$, which is indicative of hydrograph and many waterways network in the basin. High slope of the main waterway about $10 \%$ has great impact in much concentration time, rapid flow, runoff and flooding.

Another factor affecting erosion and sedimentation of basin is land use and vegetation. It is normal that regions where have suitable forest and pasture vegetation, are less prone to degradation and soil erosion. In Zemkan basin where approximately $80 \%$ of the area is covered by forest and pasture with different densities, it is expected that situation of erosion control in basin area is appropriate and erosion rate is very low, but for different reasons Including grazing permanent of pasture by livestock in the area, disregarding the balance of livestock and pasture by ranchers, applying wrong methods of plowing land, uncontrolled cutting trees, shrubs and bushes, disregarding principles of proper utilization of lands, conversion of forests and pastures to agricultural lands as well as particular morphological, physiographical and topographical features of soil and geology and effect of climatic factors specially distribution and intensity of rainfall has caused erosion status in the basin to be in very high condition. Thus, application of various methods of erosion control in the basin is essential.

\section{ACKNOWLEDGEMENTS}

The authors would like to thank Payame Noor University for providing funding this paper.

\section{REFERENCES}

Ahmadi, H. (1999): Applied Geomorphology. Vol.1, Tehran University presses.

Amini, S. Rafiei, B. Khodabakhsh, S. \& Heydari, M. (2010): Estimation of erosion and sediment yield of Ekbatan Dam drainage basin with EPM, using GIS. Iranian Journal of Earth Sciences (IJES) 2:173-180.

Amiri, F. (2010): Estimate of Erosion and Sedimentation in Semi-arid Basin using Empirical Models of Erosion Potential within a Geographic Information System. Air, Soil and Water Research 3:37-45.

Bagherzadeh, M. (1993): A Study on the Efficiency of Erosion Potential and Sediment Yield Models Using Remote Sensing and Geographic Information Systems. Msc thesis, Natural Resources College, University of Tarbiyat Modares, Tehran, Iran. 
Bayat, R. Sarmadyan, F. Darvishsefat, A.A. \& Refahi, H.G. (2001): Efficiency survey of PASIAC and EPM methods in the Taleghan basin using GIS. Journal of agriculture science. 32: 203- 217.

Borzoo, A. Momayezi, M. \& Nickandish, A. (2008): Comparison of estimating soil erosion and sediment by EPM, PSIAC and MPSIAC methods in Chehl Cheshmeh basin, Fars province. Iranian Journal of Dynamic Agriculture 5:19-29.

Bracken, L.J. \& Kirkby, M.J. (2005): Differences in hillslope runoff and sediment transport rates within two semi- arid catchements in southeast Spain. Journal of Geomorphology 68: 183 - 200.

Devente, J. \& Poesen, J. (2005): Predicting Soil erosion and sediment yield at the basin scale. Scale issues and semi-quantization Model. Journal of Earth Science 20: 131.

Gavrilovic, Z. (1988): The use of an empirical method for calculating sediment production and transport in unstudied or torrential streams. Int. Conf. for River Regime, pp. 411-422.

Ghanbarzadeh, H. \& Gholamrezaee, M.R. (2007): Potential Erosion and Sediment Estimation Using EPM Model in Catchment Basin of Arreh kamar of Fariman Using GIS, Journal of Geographical Science 7:187- 206.

Ghazavi, R. Vali, A. Maghami, Y. Abdi, J. \& Sharafi, S. (2012): Comparison of EPM, MPSIAC and PSIAC Models for Estimating Sediment and Erosion by Using GIS (Case Study: Ghaleh-Ghaph Catchment, Golestan Province). Journal of Geography and Development, 27:117- 126.

Gholami, S.H. (2003): The simulation of daily sediment yield by using distributed SWAT model in mountainous catchments (Amameh Catchments). Journal of Research and Construction, 16: $28-33$.

Gobin, A. \& Govers, G. (2003): Pan-European Soil Erosion Risk Assessment. Third Annual report. European commission funded fifth framework project-contract QLK5-CT-1999-01323. Available at: http://www.pesera. JRC.it.

Hill, J. (1993): Land Degradation and Soil Erosion Hazard Mapping in Mediterranean Environment with Operational Earth Observation Satellites. Proceedings of the international symposium of Operationalization of remote sensing, April, Enscheda, The Netherlands, pp. 19-23.

Jalili, k. \& Hadid, M. (2005): Quality and quantity evaluation of soil erosion and sedimentation by MPSIAC model using GIS. 3th conference of sedimentation and erosion.

Kyoung, J.L. Myung, S. Bernard, A.E. Zhenxu, T. Joongdae, C. \& Ki-Sung, K. (2005): GIS-based sediment assessment tool. Journal of Catena 64: 61-80.

Maghsoudi, M. Yamani, M. \& Salari, M. (2010): Estimation of erosion and sediment in Vazneh basin via assessment of effective variables with use of GIS. Journal of Geography and Development, 16: 119 - 134.

Mahmmudi, F. (2004): Dynamic Geomorphology, 6th edition, Tehran, Payame Noor university publisher.

Rangzan, K. \& Moradzadeh, M. (2006): GIS and RS application for preparing information layers of land use and land cover for MPSIAC model. Sedimentation conference. Khuzestan, Iran.

Rangzan, K. Zarasvandi, A. \& Heydari, A. (2008): Comparison of EPM and PSIAC models for estimation of erosion and sediment in Khuzestan Peghah Sorkh Getvand basin using by RS and GIS technique, Geographical Research Quarterly 64: 123-136. 
Rastgou, S. Ghahraman, B. Sanaei Nejad, H. Davari, K. \& Khodashenas, S.R. (2006): Estimation of erosion and sediment in the Tangh Konesht basin by PASIAC and EPM models using by GIS. Journal of science and Technology of agriculture and natural Resources 10: 91-105.

Refahi, H.G. (2003): Water erosion and its control, first print, Tehran, Tehran university publisher.

Refahi, H.G. \& Nematti, M.R. (1993): Using of EPM model on study of erodibility and sediment yield in the Taleghan basin. Iran agriculture science, 26: 32-45.

Sadeghi, H. (1993): Comparison of some erosion potential and sediment yield assessment models in Ozon-Dareh sub-catchment. Proceedings of the National Conference on Land Use Planning, Tehran, Iran, pp. 41-75.

Shirzadi, H. (2009): Land sliding potential in New Road, Sanandaj - Mariwan using AHP. Unpublished Msc thesis, Natural Resources College, University of Tehran, Tehran, Iran.

Sobhani, B. (2002): Comparison of FAO and MPSIAC methods for estimating sediment and erosion using GIS. Journal of agricultural sciences and natural resources 8: $15-28$.

Sokouti Oskoee, R. Broshkeh, I. Godoosi, J. \& Arabkhedri, M. (2001): Evaluation of efficiency of MPSIAC model in estimation of sedimentation five basins of Azarbaijan Gharbi province. Journal of Research and Construction 14: 35 - 37.

Tangestani, M.H. (2001): Integrating Geographic Information System in erosion and sediment yield applications using the Erosion Potential Method (EPM). Proceedings of the 9th annual conference of the GIS Research UK, eds: D.B. Kinder and G. Higgs, 18-20 April, University of Glamorgan, Wales.

Tangestani, M.H. (2006): Comparison of EPM and PSIAC models in GIS for erosion and sediment yield assessment in a semi-arid environment. Afzar Catchment, Fars Province, Iran. Asian Journal of Earth Sciences 27: 585 - 597.

Ziaee Esfandrany, H. (2004): GIS and RS application for sediment and erosion estimation of Shahid Abbaspour dam watershed. MS thesis. Shahid Chamran University. 